Scientia Militaria vol 40, no 3, 2012, pp.147-176. doi: 10.5787/40-3-1038

\title{
Guiding the Seafarers: The South African Hydrographic Office and the Contribution of the Three Proteas
}

\author{
Thean Potgieter ${ }^{\bullet}$
}

\begin{abstract}
As seafarers require a comprehensive record that provides information on coastlines, the seabed and sea conditions, cartography dates back to antiquity. During the early modern period, states and merchant companies employed cartographers to collect and report important nautical information. The Dutch East India Company (VOC), for example, created valuable nautical charts and provided detailed sailing instructions on the South African coast. Open exchange of such information is a twentieth-century phenomenon dating back to the creation of the International Hydrographic Organisation (IHO) in 1921. The SA Navy was created in 1922. One of its first ships was the survey ship HMSAS Protea, which was laid up in 1933. During the two decades following the Second World War, hydrographic survey work was done by three converted former Royal Navy vessels (SAS Protea, SAS Natal and SAS Haerlem). South Africa became a member of the International Hydrographic Organisation (IHO) in 1951 and the SA Navy established its own Hydrographic Office in April 1955. The SA Navy's Hydrographic vessels were always outdated or redundant ships, but in 1972 the SA Navy commissioned its first purpose-built hydrographic survey ship (the current SAS Protea).
\end{abstract}

Keywords: Protea, hydrography, charting, SA Navy, survey ship

- Prof Thean Potgieter is a research fellow of Centre of Military Studies (CEMIS), Stellenbosch University and is a former Director CEMIS. He is currently Chief Director Research and Innovation at the Public Administration Leadership and Management Academy of South Africa (PALAMA). 


\section{Introduction}

The SA Navy Hydrographic Office and its survey vessels (specifically the three Proteas) contributed substantially towards charting South African waters. South Africa is a respected member of the IHO and provides the professional hydrographic service the international maritime community requires for safe navigation around the South African coast.

In order to navigate the oceans and coastlines of the world seafarers require a comprehensive record providing information on coastlines, the seabed, dangers to shipping and the conditions that might be expected. Accurate information is very important as the history of seafaring is full of examples of inaccurate or incomplete information contributing to maritime disasters, causing not only loss of life and material, but also environmental damage.

Maritime trade is one of the most important activities of coastal states. Historically, only surface vessels provided commercial links, communication, military contact and maritime interaction with the wider world. Today, such contact in the maritime domain also occurs via pipelines, telecommunication cables and even submarines. Such activities are, however, be supported by a variety of state and non-state agencies, reliable hydrographic and geographic information, navigation aids, a search and rescue capacity, as well as laws, rules and regulations. Coastal states are responsible for hydrographic surveys and the production of up-to-date charts and other publications that provide accurate nautical information to ensure safe passage. Hydrographic offices are usually state departments and, in the case of South Africa, it resorts under the SA Navy.

The South African coast has historically been a graveyard to shipping, and even in contemporary times, despite technological advances in shipping and equipment, shipwrecks and nautical disasters are still common. Much of the coastline is rocky and inhospitable, often with reefs close inshore, while sea conditions can be severe with high swells and frequent storms. Maritime communications are of the utmost importance to Southern Africa as South Africa's network of ports (unmatched in Africa) handles the imports and exports of various states in the region as well as about ninety per cent of the bulk and eighty per cent of the value of South Africa's 
international trade. ${ }^{1}$ As sea-borne trade is an essential ingredient for the economic development of the region, the protection of shipping, sea lanes of communication, maritime resources and harbours are very important. This fact is even recognised by those land-locked states in the region that do not have direct access to the sea.

The SA Navy Hydrographic Office and its survey vessels, specifically the three Proteas, have made a considerable contribution during the twentieth century towards keeping the South African coastline safe for international navigation. This article will focus on that contribution and the active careers of the three Proteas.

\section{Hydrography and the Charting of the South African Coastline}

Accurate information essential for safe navigation is collected through a process known as hydrographic surveys, and the data collected are made available to navigators through charts and a large variety of nautical publications. Hydrography or nautical surveying can be defined as "the collecting of bathythermic and other data", while marine cartography is "the collecting, correlating, collating, editing, compiling and reproduction of data in various formats". ${ }^{2}$ The distinction between maps and nautical charts is apparent. Maps concern land surveys represented in cartographic form, while charts are navigational aids that must clearly indicate all features and dangers that are likely to affect the safe passage of a vessel. They include data such as depths, contours, navigational aids, information on the bottom, and other information navigators might require.

Cartography dates back to antiquity as knowledge of oceans has always been important to mariners. Through the ages, seafarers meticulously recorded information on prevailing winds, doldrums, currents, dangers and possible places for provisioning in their ships' logs and on early charts. Much guesswork occurred, places were often wrongly recorded, or islands were recorded where there were none, as navigators made errors relating to latitude and dead reckoning during their voyages. Many charts were therefore poor and contained sparse or insufficiently surveyed information. 
By the early eighteenth century, hydrographic standards that were to last in the same general form for more than two centuries were established and as science improved the requirements for proper charts grew. States and merchant companies used to employ cartographers to collect and report important nautical information. However, such information was not openly shared and its use was mostly restricted to its owners. Open exchange of hydrographic data is essentially a twentieth-century phenomenon dating back to the creation of the International Hydrographic Organisation (IHO) in 1921. Today, the IHO sets formats and standards, develops skills and promotes the exchange of data.

Recent international agreements and regulations have gone beyond encouraging the sharing of data as states are in effect legally responsible for safety at sea and providing data to improve safe navigation. In July 2002, changes to the International Convention on Safety of Life at Sea (referred to as SOLAS V) came into force, emphasising safe navigation and stating that when intelligence of any dangers is received, "it shall be promptly brought to the knowledge of those concerned and communicated to other interested Governments". Contracting governments are obliged "to arrange for the collection and compilation of hydrographic data and the publication, dissemination and keeping up to date of all nautical information necessary for safe navigation". 3 The UN General Assembly also accepted a resolution (A/53/32 of 1998) requesting coastal states to carry out "hydrographic surveys" and to provide nautical services to ensure safe navigation and "uniformity in charts and nautical publications and to coordinate their activities so that hydrographic and nautical information is made available on a worldwide scale". ${ }^{4}$

Though the basic data required for charts have in essence been maintained, technology has brought vast changes to data collection methods and the processing and dissemination of information. Contemporary navigational equipment and electronic sensors make the process of sounding and fixing a position much easier. During hydrographic surveys, the area seaward of the low-water mark would typically be surveyed by taking soundings in regular and evenly spaced lines and the position and depth of any obstructions precisely determined and noted. In addition, the nature of the sea bottom, data on tides and currents, magnetic variations, as well as all 
other features that might affect navigation, including topographical information on the landward side, are precisely measured and recorded. ${ }^{5}$

Surveys are recorded and digitally produced in a fair chart version, which is checked and collated for any anomalies. New information, including data collected by satellite imagery and aerial photography, is then compared with archived data. After taking all changes and new information into consideration a new chart is produced. ${ }^{6}$

Besides a large variety of charts and electronic navigation charts, hydrographers also produce various publications which include Sailing instructions (a "script" chart in book form which supplements charts and provides valuable information that would be difficult to display on a chart), tide tables and lists of lights. Furthermore, hydrographic offices must constantly send out notices to navigators that would indicate new information and warnings on navigation dangers. Charts are constantly updated to display this, but important or urgent warnings to shipping are also done by radio. ${ }^{7}$ Because of the exact scientific nature of hydrographic surveying, it is vast and time-consuming work.

Although South Africa has a rugged coastline that is difficult to survey, the advantage is that this coastline is mostly stable and the tidal range is on average around two metres. The history of charting the South African coastline can be traced back to the early Portuguese seafarers who created rudimentary charts and documented their voyages in logbooks. Such elementary data provided only basic navigational aids and seafarers often had to rely on their instincts, logic and skill when rounding the southern tip of Africa.

The Dutch East India Company (Vereenigde Oost-Indische Compagnie or VOC) created valuable charts of the South African shoreline and meticulously documented dangers as well as sea conditions. The first chart of Table Bay after the arrival of the Dutch was made in 1652-1653, presumably by Caspar van Weede (Secretary to the Council of Policy). It shows the Fort in Table Bay and contains positive remarks on the Cape, but is not worth much as a chart. A chart with some value was made in 1654 (presumably also by Van Weede) showing the coast from Saldanha Bay to False Bay. However, this chart contains many errors in distances, 
relationships and the shape of areas such as Saldanha Bay and the Cape Peninsula. ${ }^{8}$ Soon, more accurate charts appeared, for instance the coastal chart produced by the surveyor Pieter Potter in 1658-1659. His chart of Saldanha Bay in essence corresponds with the facts and the scale is more realistic than previous attempts. ${ }^{9}$ By the late eighteenth century, VOC charts on the South African coast, specifically the Cape, were generally quite accurate and included good land profiles to further guide the seafarers. Of the surprising number of beautiful charts and coastal profiles that have survived, those by Schumacher and Gordon (1777), Barbier (1786-1787) and Federici (1788) are particularly noteworthy. ${ }^{10}$

By the middle of the eighteenth century, the VOC also provided their captains with thorough sailing instructions on the South African coast, contained in their standing orders. It included detail on the coastline, sea conditions, prevailing winds, dangers to shipping, instructions on entering Table Bay and using the anchorage, notes on Saldanha Bay and Hout Bay as well as sailing directions for entering False Bay and anchoring in Simon's Bay. ${ }^{11}$

In 1822, the British authorities at the Cape instructed Captain William Owen of the Royal Navy to survey the East Coast of Africa starting at the Cape. Owen was given three ships for the task and returned to Cape Town in 1825. Owen and his capable lieutenants then set out to survey the West Coast of Africa northward of the Congo River mouth. They arrived in Britain five years later, having charted 55000 kilometres of coastline. Despite his limited resources and time, Owen's work has surprising accuracy and detail. The first charts of South African waters based on Owen's surveys were published soon afterwards (False Bay in 1829 and Algoa Bay in 1849) and contemporary charts in some cases still contain data that he collected. ${ }^{12}$ After Owen, numerous surveys followed and various charts and sailing instructions of the South African coast were published. The first comprehensive series of charts of the South African coastline, from Hondeklip Bay to Port Natal, were published in 1867.

During the Anglo-Boer War (1899-1902), the British government realised that they lacked proper maps and detailed charts of the South African coast. After the war, colonial authorities were requested to create survey departments. Between 1910 and 1913, the coast of Natal, from 
Durban to Cape St Lucia, was surveyed by Captain E.C. Hardy and Lieutenant Commander J.A. Edgell of the Mutine. Their work is surprisingly accurate and they produced four fair charts that are often regarded as the first examples of modern charts of the South African coast. Specifically remarkable is the fact that they measured depth up to a 100 fathoms (180 metres) with hand leadlines. ${ }^{13}$

During the First World War, no surveying was done. After the war, a small South African naval establishment was created. One of its first ships, the HMSAS Protea, was a survey ship.

\section{The Creation of the South African Navy and the first Protea}

The history of hydrographic surveying in the SA Navy goes back to its creation. As a consequence of the decisions taken at an Imperial Conference in London early in 1921, South Africa would discontinue its annual financial contributions to the Royal Navy (RN) and instead take responsibility for the hydrographic survey of South African waters, form a seagoing naval permanent force, expand the South African Division of the Royal Naval Voluntary Reserve (RNVR) to provide a pool of reserves and bear the cost of specified developments in the Simon's Town dockyard. ${ }^{14}$

The British Admiralty availed three small ships to South Africa, which arrived in False Bay on 11 January 1922. ${ }^{15}$ They were re-commissioned as South African ships on 1 April 1922. HMS Crozier, a Hunt class minesweeper was converted into a survey ship and renamed the HMSAS Protea, while two minesweeping trawlers, HMS Foyle and HMS Eden became the HMSAS Sonneblom and HMSAS Immortelle. The crews belonged to a new arm of the Union Defence Force (UDF), the South African Naval Service (SANS), which became a permanent unit of the UDF on 1 February 1923.

At this stage, the existing Admiralty charts compiled by the Royal Navy Hydrographic Office were based on a collection of data gathered by various ships stationed at the Cape and information submitted by ships traversing South African waters. As recently as the middle of the twentieth century, some of the data used on South African charts had still been 
gathered as much as two centuries earlier with hand leadlines and dated navigation equipment. ${ }^{16}$

HMSAS Protea began the proud survey tradition of the SA Navy. After the SANS had requested the services of an experienced hydrographer from Britain, Lieutenant Commander A.F.B. Woodhouse (RN) was seconded to the SANS in 1924 and became the Officer Commanding of the HMSAS Protea. From 1924 to 1927, Woodhouse completed three important surveys and updated the Admiralty charts on the coastline between Durban and East London. ${ }^{17}$ Lieutenant Commander J. Dalgleish of the SANS took over command of the HMSAS Protea on Woodhouse's return to the Royal Navy in 1927. Dalgleish, whose name appears on many charts of the South African coast, surveyed the rocky West Coast from St Helena Bay to Table Bay. Unfortunately, during the thirties, defence expenditure was severely curtailed as a result of the Great Depression. The SANS suffered badly and could not be kept operational. The HMSAS Protea was paid off on 30 April 1933 and by 1934 SANS had disappeared as a seagoing force. Only a skeleton staff of four officers and twelve ratings remained. One of its tasks was still hydrographic survey work, which was done a few months per year in conjunction with the Department of Sea Fisheries by the fisheries research vessel Africana. ${ }^{18}$

\begin{tabular}{|l|l|}
\hline \multicolumn{2}{|c|}{ HMSAS PROTEA SPECIFICATIONS ${ }^{19}$} \\
\hline Length, overall & $70,4 \mathrm{~m}$ \\
\hline Beam & $8,71 \mathrm{~m}$ \\
\hline Draught & $2,29 \mathrm{~m}$ \\
\hline Displacement & 800 tons \\
\hline Armament & One 3-pounder gun \\
\hline Speed & 16 knots \\
\hline & $\begin{array}{l}\text { Two Yarrow water tube boilers and two furnaces } \\
\text { Two coal-fired vertical triple-expansion steam 3- } \\
\text { cylinder reciprocating engines, with two propeller } \\
\text { Machinery }\end{array}$ \\
& shafts, 2 200 hp \\
\hline Endurance & 7 500 nautical miles at 15 knots \\
\hline Complement &
\end{tabular}


The second vessel to carry the name HMSAS Protea was not a survey ship, but a Terje Class whaler converted into an anti-submarine warfare vessel. She served with distinction in the Mediterranean theatre during the Second World War and even succeeded in sinking an Italian submarine, the Ondina, in July $1942 .^{20}$

\section{The South African Navy Hydrographic Office}

South Africa became a member of the International Hydrographic Organisation (IHO) in 1951. After ministerial approval was granted in 1954, the South African Navy Hydrographic Office (SANHO) was established in Cape Town on 1 April $1955 .{ }^{21}$ The most important consequence was that South Africa could now publish its own charts rather than having to submit the data it collected to the Royal Navy hydrographer in the UK.

By 1962, the hardworking SANHO had already produced 16 charts covering important South African harbours and some sections of the coastline. These charts were initially printed by the Government Printer in Pretoria, but after the establishment of the SA Navy Publications Unit Printing Division in 1960, South African charts and hydrographic publications were printed in Simon's Town. In addition, SANHO also provided the hydrographic information required for national defence.

South Africa is a respected member of the IHO that fulfils its regional and international obligations by aiding safe navigation and providing the professional hydrographic service the international maritime community requires for safe navigation around the South African coast. ${ }^{22}$ Many countries that produce their own series of charts compile them from data provided by the South African hydrographer.

In addition to its national charting responsibility (covering the waters of South Africa and Namibia), South Africa also provides coverage in the IHO Charting Region H (Southern Africa and adjacent islands) and Region M (Antarctica, covering the approaches to Dronning Maud Land where the South African research station SANAE IV is based). ${ }^{23}$ The products the SANHO produces include navigation charts; training charts and fishing plotting charts; navigational publications such as the SA Sailing Directions, 
the SA List of Lights, the SA Tide Tables, the SA Catalogue of Charts and Publications; the SA Symbols and Abbreviations; coastal navigational warnings issued for transmission via coastal radio stations; and Electronic Navigational Chart products. ${ }^{24}$ SANHO is the only hydrographic organisation in Africa that produces electronic navigational charts.

In June 2009, Captain (SAN) Abri Kampher, the SA Navy Hydrographer, received the very prestigious Alexander Dalrymple Award for services to hydrography. The award symbolises recognition for outstanding dedication and contribution to world hydrography and it was the first time that it was awarded to a hydrographer outside Europe (the three previous recipients were from the UK and Germany). ${ }^{25}$ Kampher is a highly respected figure in the IHO and has received recognition for his contribution towards developing hydrographic and cartographic expertise and capabilities in the Southern African region. He has also chaired a major task group on the Worldwide Electronic Navigational Database, which is crucial for the creation of electronic navigational charts. Indeed, as Rear Admiral Ian Moncrieff (UK National Hydrographer) reiterated:

Despite difficulties in retaining a small qualified staff of just 24 people, the South African Office is a mature centre of expertise in the region. Abri has worked painstakingly, often in isolation, to represent the region and develop its capabilities. $^{26}$

\section{The Third Protea and the SAS Natal}

Following the Second World War to the early seventies, hydrographic survey work was done by three converted vessels, the HMSAS Protea, the SAS Natal and the SAS Haerlem. The third ship to carry the name Protea was a former Flower Class corvette. After the War, the SA Naval Forces (the SA Navy from 1 January 1951 onwards) acquired a corvette, HMS Rockrose, to convert into a survey ship, as the urgent hydrographic survey work had been interrupted by the Second World War. ${ }^{27}$

Flower Class corvettes were renowned for their role as anti-submarine escorts during the Battle of the Atlantic in the Second World War, but the Rockrose had to undergo extensive conversion to fulfil her new role as survey ship. The conversion took place in Durban. For greater comfort in South African conditions, her steel decks were covered with wood, while the 
living spaces, accommodation and on-board facilities were improved. A higher bridge was fitted for clearer visibility and she was equipped with special derricks and davits to handle dan buoys, beacons and survey motor launches. The process was complete by middle February 1950 and she was commissioned as the HMSAS Protea. A month later, she departed on her first survey voyage under the command of Commander R.T. Tripp (RN), a South African and a qualified hydrographer who was seconded from the Royal Navy. ${ }^{28}$

\begin{tabular}{|l|l|}
\hline \multicolumn{2}{|c|}{ HMSAS PROTEA SPECIFICATIONS ${ }^{29}$} \\
\hline Length, overall & $62,5 \mathrm{~m}$ \\
\hline Beam & $10,8 \mathrm{~m}$ \\
\hline Draught & $4,12 \mathrm{~m}$ \\
\hline Displacement & 1060 tons (standard) 1340 tons (full load) \\
\hline Speed & 16 knots \\
\hline & Two cylindrical single-ended boilers \\
Machinery & One 4-cylinder vertical triple-expansion steam \\
& reciprocating engine, 2750 hp \\
\hline Endurance & 3450 nautical miles at 12 knots \\
\hline Complement & 82 \\
\hline
\end{tabular}

HMSAS Protea's first task was to survey part of Table Bay. She then proceeded to Algoa Bay to survey the Bird Island Passage - a rather urgent task as the data used on the Admiralty charts were essentially based on a survey Francis Skead did more than a century earlier. After that, surveys of sections of the Eastern and Southern Cape Coast as well as the Walvis Bay harbour area followed. Late in 1952, the SAS Protea (SAS replaced the prefix HMSAS on 20 June 1952) had to dash to Marion Island on a mercy mission to rescue a man for an urgent appendectomy. The voyage stretched her endurance to the limit and she had only fifteen tons of fuel left on her return. $^{30}$

As a converted Flower Class corvette, the SAS Protea was not the ideal hydrographic survey ship. She was rather cramped and crowded in her new role, and because of her design characteristics she was very lively in the South African sea conditions. Also, her hard-worked boilers and engines 
were ageing and due to her limited electrical capacity, it was difficult to manage the complex electronics on board. She was paid off in January $1957 .{ }^{31}$

As survey work had to continue a Loch Class frigate, the SAS Natal, was converted into a survey vessel at the Simon's Town dockyard and recommissioned in 1958. SAS Natal had an exemplary fourteen-year career as a survey vessel and managed to complete 62 surveys in South African waters. In addition, she participated in a number of international oceanographic studies covering the Southern Oceans as well as an international Indian Ocean expedition during which she found and charted the shallow shoal water over the Madagascar ridge. In 1963, one of the Ford Class seaward defence boats, the SAS Haerlem, was also converted into a survey vessel to assist the SAS Natal with survey duties in coastal and shallower waters. By the late 1960s, SAS Natal was reaching the end of her active career and a replacement, the current SAS Protea, was ordered. The SAS Natal was decommissioned in March 1972 and SAS Haerlem was paid off five years later. ${ }^{32}$

\section{SAS Protea, the first "real" hydrographic survey vessel}

The hydrographic branch always had to make do with obsolete or redundant ships refitted for survey work. This was not the ideal situation and it was often difficult to keep old vessels, or vessels unsuited for their task, operational. This changed in 1972 when the SA Navy commissioned its first purpose-built hydrographic survey ship.

As the SAS Natal was reaching the end if her seagoing life in the late 1960s, the SA Navy decided to acquire a new survey ship. On 7 November 1969 a contract to build a survey ship for $£ 2503500$ (pounds sterling) estimated at R4 306020 (ZAR) at the time, was signed with the British shipyard Yarrow. ${ }^{33}$ Yarrow had a good working relationship with the SA Navy: they built two of the President Class frigates and also conducted a study on the local shipbuilding capabilities for the SA Navy. However, due to the international renunciation of apartheid, political attitudes were turning against South Africa and Britain placed an embargo on the selling of warships to South Africa. Yarrow therefore first had to request permission from the British Ministry of Defence to proceed with the project. The 
Ministry considered a survey ship as "non-military" and informed Yarrow in August 1969 that building the ship for "South Africa will not meet any difficulties". ${ }^{34}$

The design of the new ship was based on the Hecla Class vessels of the British Royal Navy. These vessels were purpose-built for oceanographic research and hydrographic survey work in accordance with commercial standards, as opposed to naval standards. They therefore had a slower and more rounded hull design than is usual for naval vessels. Building at the Yarrow Yard on the Clyde in Scotland commenced early in 1970. However, strikes and industrial action caused the launching, final completion and delivery dates to move to the right a number of times. ${ }^{35}$ The South African Embassy in London often whinged to the Chief of the SA Navy about the lack of progress, describing it as a "neerslagtige situasie" (a depressing situation) and complaining that "Yarrow staak geheel en al" (Yarrow is totally on strike). ${ }^{36}$ The ship was launched on 14 July 1971 and her sea trials eventually took place during April 1972. She was named the SAS Protea (the fourth South African naval vessel to carry the name), was commissioned with Captain (SAN) A. Fawthrop as her first officer commanding and sailed for South Africa on 6 June 1972. ${ }^{37}$

During the voyage home, the SAS Protea visited Lisbon, Luanda and Walvis Bay. On arriving in Simon's Town, on 14 July 1972, she was welcomed by the Minister of Defence, P.W. Botha with the SA Navy Band and a large crowd in attendance. Cape Town newspapers reported on the arrival of a new and modern, well-equipped survey ship, describing her as a "sleek ship ... the country’s pleasure ...", well worth the money spent. ${ }^{38}$

In order to ensure that the SAS Protea remains up to date and operational she is generally well maintained and has received constant upgrades of on-board equipment, machinery, propulsion system, electronics and navigation aids. She was initially equipped with four Paxman diesel engines, but when these engines reached the end of their service life in 1996, they were replaced by four more effective MTU diesels during a major refit. Her four main engines can be used in combination, or on their own, and are linked through a central gearbox to one shaft and a controllable pitch propeller. She is also equipped with a transverse bow thruster for enhanced manoeuvrability. The SAS Protea has very good sea-keeping capabilities in 
all climates as she is equipped with a passive roll stabilising system (reducing roll by up to 60\%) and a strengthened bow (not an icebreaking bow) for operations in Arctic and Antarctic conditions. ${ }^{39}$

\begin{tabular}{|c|c|}
\hline \multicolumn{2}{|c|}{ SAS PROTEA SPECIFICATIONS ${ }^{40}$} \\
\hline Length, overall & $79,3 \mathrm{~m}$ \\
\hline Beam & $15,0 \mathrm{~m}$ \\
\hline Draught & $4,9 \mathrm{~m}$ \\
\hline Displacement & 1930 tons (standard) 2750 tons (full load) \\
\hline \multirow[t]{3}{*}{ Machinery } & $\begin{array}{l}\text { Original engines were four } 12 \text { cylinder Paxman } \\
\text { Ventura Mk II diesel engines, producing up to } 1320 \\
\text { bhp each } \\
\text { Engines geared to a controllable pitch propeller }\end{array}$ \\
\hline & $\begin{array}{l}\text { In 1996, the original engines were replaced by four } \\
\text { 12-cylinder MTU diesels, combined output is } 3940 \\
\text { kilowatts }\end{array}$ \\
\hline & One traverse bow thruster \\
\hline \multirow[t]{2}{*}{ Endurance } & 17000 nautical miles at 12 knots \\
\hline & Original engines, 12000 nautical miles at 12 knots \\
\hline Speed & 16 knots \\
\hline Complement & 17 officers and 107 NCOs \\
\hline Helicopter & $\begin{array}{l}\text { Initially, a Westland Wasp helicopter, later replaced } \\
\text { by an Alouette III helicopter }\end{array}$ \\
\hline Survey craft & 2 x survey motor launches \\
\hline
\end{tabular}

As the primary function of the SAS Protea is to conduct independent survey operations for long periods without regular visits to ports, she has good endurance and self-maintenance capacity. She can carry up to seven scientists, support personnel and medical staff and is also fitted with a theatre and a small hospital. She has a library, canteen, laundry, large storage spaces as well as electrical and machinery workshops on board. Electricity is provided by four on-board generators, with a capacity of about 4000 ampere (enough to supply the needs of a large town). In addition, she can produce as much as 900 litres of fresh water from seawater per hour and a sewerage treatment plant is used to prevent harbour and sea pollution. ${ }^{41}$ 
The SAS Protea is well equipped to perform her primary role hydrographic survey work. Her survey system has been upgraded a number of times and currently she has a modern survey system and supporting equipment with a central area network and workstations. It includes a deep sea echo sounder and a multi-beam system with a $3000 \mathrm{~m}$-range capability and can perform sea-bottom profiling for the location of underwater objects. Other equipment includes integrated electronic measurement and control systems for data logging, a computerised steering system which enables the ship to stay on a specific predetermined track while surveying, and a highly accurate navigation system that ensures pinpoint position fixing. Temperature, density, sound velocity and salinity readings are constantly taken in order to establish the speed of sound through the water under different circumstances to a depth of 1500 metres. Two well-equipped survey boats (also fitted with multi-beam echo sounders) are carried to perform independent survey tasks closer inshore and in shallow waters. The data collected by the boats can be transferred to the main network. This is a state-of-the-art survey system and much of the software used was developed in South Africa. ${ }^{42}$

The large chart room and drawing office on board provide good space for survey plotting and serves as a survey office. The ship also has a helicopter hangar and deck aft. Initially, she operated a Westland Wasp helicopter, ${ }^{43}$ but after these helicopters were taken out of service, it was replaced by an Alouette III. The helicopter principally does aerial surveys and is used to place markers and survey slave stations and personnel ashore in locations that are difficult to access. Motorcycles and quad bikes, stored on board the ship, are used to support survey operations ashore.

\section{Protea's long active career}

The SAS Protea has had a busy seagoing career spanning four decades. This includes many transoceanic voyages, visits to foreign ports and interesting parts of the world as well as the arduous survey work in Southern African waters. Apart from her survey role, she has proved to be an extremely versatile vessel performing a variety of tasks, including numerous assistance operations, which have earned her the affectionate nickname "White Lady". 
No other SA Naval vessel has frequented the Southern Oceans as often as the SAS Protea. Because of her ice-strengthened bow, she can operate in Antarctic conditions and pack ice, but not thick ice as she is no icebreaker. The first such visit was to the Island of Tristan De Cunha in 1972. The SAS Protea has become a regular visitor to Marion Island, one of South Africa's Prince Edward Islands in the south Indian Ocean. She visited Marion Island for the first time in November 1974 to assist scientists based on the island with the building of new huts on various locations around the island. Three years later (1977), SAS Protea visited Marion Island to do survey work and take soundings. ${ }^{44}$ At the same time she transported a number of scientists who were tasked to get rid of the cat population on the island. ${ }^{45}$ Cats were taken to Marion Island to get rid of the rats that arrived with the first human beings by accident. The cat population, however, soon flourished and threatened to cause an ecological imbalance as they did not prey on the rats, but instead targeted many of the birds (and their eggs) nesting on the island.

Within the space of a year, SAS Protea also performed two mercy missions to Marion Island. The first one was in July 1984 to rescue $\mathrm{Mr}$ Graham Clarke, the leader of the scientific expedition on the island, who suffered a stroke. Due to severe winter conditions the rescue effort was very difficult and it was only possible to airlift Clarke with the ship's helicopter during the third attempt. ${ }^{46}$ A year later, in July 1985, SAS Protea had to fetch Mr D. Linde, who had incurred a serious eye injury and required urgent specialist attention. Specifically the first rescue caused considerable interest in the media, and the ship's company received much praise, as a report in the Sunday Times testifies:

In dreadful conditions, rescuers spared no efforts to bring the young scientist out of the Antarctic home to proper medical care. The mercy mission underlies the vital importance of those ... who imperil themselves to save other lives. ${ }^{47}$

During 1987, the SAS Protea returned to Marion Island, this time to do survey work and to assist officials of the Department of Environmental Affairs with a feasibility study concerning an airstrip on the island. ${ }^{48}$

In March 1975, the SAS Protea went to Kergeulen Island in the South Indian Ocean to support six South African mountaineers who endeavoured 
to climb Mount Ross Peak on the island. ${ }^{49}$ The expedition failed due to bad weather and also met with tragedy when the ship's doctor (Dr Ferreira) was killed on the island when he accidentally walked into the tail rotor of the Wasp helicopter. ${ }^{50}$ Despite the often dangerous conditions under which members of the ship's company have to work, this has been the only fatal accident involving a crew member.

In 1978, the SAS Protea participated in an international scientific project in the southern oceans. Because there was no suitable civilian vessel available, the Department of Sea Fisheries, the Department of Industry and representatives of the University of Cape Town requested the SA Navy in December 1976 to assist with an international research project focusing on Antarctic marine life, food resources and krill. ${ }^{51}$ At the same time, she had to lay 40 weather buoys in the South Atlantic as part of an international global warming experiment. The Chief of the SA Navy, Vice-Admiral J.C. Walters (a former hydrographer), was quick to grab the opportunity, stating that "in the interest of scientific research there is justification to provide Protea to collect the data". ${ }^{52}$ On 10 February 1978, SAS Protea, with a team of scientists on board, departed from Simon's Town on what became a memorable ten-week voyage. During the voyage, SAS Protea became the first SAN vessel to round Cape Horn, she also sailed through the Beagle Channel to Ushuaia (the southernmost town in the world), visited the South Shetland Islands, South Georgia Island and the Argentine naval base Porto Belgrano. $^{53}$

SAS Protea had the good fortune to visit Antarctica twice. The first time was in January 1993 in support of the South African Antarctic programme when she had to transport 34 scientists to Antarctica. The scientists were transferred to the South African polar expedition vessel $S A$ Agulhas, and SAS Protea also replenished the Agulhas in the Antarctic. ${ }^{54}$ During this voyage, she became the first SA Naval vessel to cross the Antarctic Circle twice and to move into the pack ice as far as $70^{\circ}$ south. In January 1994, she went to Antarctica again, this time to exchange the SA Air Force crew at the South African research base (SANAE) in Antarctica and to transport extra stores and much needed spares to Antarctica for the Department of Environmental Affairs. ${ }^{55}$ 
The following year, SAS Protea again sailed into the southern oceans with an environmental objective. This time she had to lay a pattern of floating weather buoys for the South African Weather Service in order to obtain valuable weather data. During the six-week voyage, she went alongside at Grytviken on South Georgia Island and anchored on the leeside of Gough Island. While anchored at Gough, the on-board engineers had to fix one of the bow thruster doors. This was done by emptying all the forward ballast tanks to the stern and lifting the bows so that technical staff could move into the bow thruster compartment. ${ }^{56}$

Besides the rescue voyages to Marion Island discussed above, the SAS Protea also conducted a variety of other search and rescue operations through the years and has received much recognition in this regard. Only some of these would, however, be cited. May 1978 was particularly busy in this regard. On 25 May, the SAS Protea rescued 26 crew members of the sinking Japanese trawler Kayo Maru between the Kunene River mouth and Möwe Point. The helicopter managed to put the crewmen ashore with ample provisions (including alcoholic beverages) by 15:00. Due to the harshness of the desert climate, Captain (SAN) C.J.H. Wagenfeld of the SAS Protea felt that they would be safer on board. Another nine helicopter sorties followed and the marooned crew was safely on board the SAS Protea by 19:00. By that time, however, as the official report dryly states "the castaways had made the most of their stay ashore, having consumed most of their liquid refreshments, many arrived on board in a euphoric state". ${ }^{57}$ On 27 May, the Kayo Maru's crew disembarked at Walvis Bay. A few days later (on 31 May), SAS Protea had to rescue a crew member who had suffered a heart attack on the oil tanker Texaco Sweden, in the same vicinity. ${ }^{58}$ Captain Armstrong, Master of the Texaco Sweden, was full of praise, writing to Wagenfeld, "your action exemplifies the time honoured tradition of the sea". ${ }^{59}$

In 2000, the SAS Protea interrupted an East Coast survey to sail down to Gough Island to rescue two crayfish fishermen. After a botched rescue effort by their trawler, two fishermen were dead and two were marooned on the island. After SAS Protea's arrival, the fishermen and the bodies were quickly airlifted to the ship. ${ }^{60}$ On 2 November 2009, while the ship was busy with survey work due east of Durban, she responded to a mayday call (at 22:15) from the sinking Spanish registered fishing trawler, Acechador. 
She assisted with the rescue of the seventeen Spanish crew members and took them to Durban. ${ }^{61}$

The SAS Protea is also one of the SA Navy's most accomplished diplomats. The good relations that existed during the first few decades after the Second World War were systematically eroded as South Africa was politically ostracised because of apartheid. In terms of foreign visits and naval diplomacy, the 1970s and 1980s saw little activity and South Africa's international isolation as well as its decision to abandon the Navy's bluewater role and focus on the defence of South Africa's harbours, coastline and maritime interest, clearly had a great impact.

Yet, the SAS Protea still managed a few visits during this time. In 1976, she acted as guard ship for the Cape to Rio de Janeiro (in Brazil) yacht race. After visiting Rio de Janeiro, she put in at Buenos Aires (Argentina). ${ }^{62}$ Due to political considerations, the finishing point of the 1979 transatlantic yacht race switched from Rio de Janeiro to Punta del Este in Uruguay. SAS Protea again acted as guard ship. ${ }^{63}$ She departed from Simon's Town on 13 January and returned on 10 March 1979. During this voyage (January to March), she also visited Montevideo, Uruguay and Buenos Aires, Argentine, hosting diplomatic receptions on board. ${ }^{64}$

Hereafter formal naval contact became extremely limited and for more than a decade very little flag-showing visits took place. When South Africa emerged from years of isolation under apartheid, the SA Navy contributed much towards normalising international relations and in some cases even forged new relations. SAS Protea was again eminent. In 1990, when she acted as guard ship for the Dias yacht race from Cape Town to Lisbon, she became the first SA Navy ship to visit a NATO port since 1976. On the return voyage, her Captain, Commander B.H. Teuteberg, fell ill and the ship had to put in at Abidjan in the Ivory Coast. ${ }^{65}$ Though Teuteberg stayed behind when the SAS Protea sailed, he soon recovered and went home.

An invitation to South Africa to participate in the 1992 IHO Conference in Monaco was regarded as the ideal opportunity for a vessel of the SA Navy to visit the Mediterranean and the Black Sea in order to host a number of official functions in support of the Department of Foreign Affairs. During the subsequent voyage, the SAS Protea visited Monaco, the 
Italian port of Genoa, Istanbul in Turkey, and Constanta in Romania. The return voyage was via the Suez Canal. The SAS Protea became the first South African naval vessel to sail through the Dardanelles and Bosporus into the Black Sea, as well as the first naval vessel to visit Mediterranean ports such as Genoa and to sail around Africa since the Second World War. ${ }^{66}$

In March 1993, SAS Protea was part of a joint South AfricaMozambique project aimed at establishing the exact sea border between the two countries. Six officials from the South African Department of Environmental Affairs and six Mozambican officials monitored the survey operations the SAS Protea undertook. At the completion of the survey, SAS Protea went alongside in Maputo, the first South African naval vessel to do so since Mozambique gained independence. ${ }^{67}$

One of the interesting international support operations SAS Protea participated in was Operation Lariat in April 2001. After the Australian government had requested South African assistance to intercept a Spanish trawler, the Sao Tomé, that was fishing illegally in the Australian exclusive economic zone (EEZ), the SAS Protea, with Captain (SAN) Abrie Kampher in command, and the strike craft SAS Galeshewe, under Commander Mickey Girsa, sailed from Simon's Town to intercept the poacher. The SAS Protea had an Australian team on board, and on 12 April, about 260 miles south of Cape Agulhas, the task force intercepted the Sao Tomé with the unarmed Australian civil patrol vessel Southern Supporter still in hot pursuit. When the skipper of the Sao Tomé saw the well-armed SAS Galeshewe blocking his way, he stopped his vessels and allowed the Australian team to board. ${ }^{68}$ The operation resulted in complimentary messages from the Australian government, and poses a firm warning that South Africa and Australia intend to cooperate in the preservation of marine resources.

Due to the fact that SAS Protea carries adequate victuals and fuel, she is also able to replenish and support smaller vessels during extended operations. ${ }^{69}$ In 2006, the SAS Protea, under the command of Captain (SAN) Mark Blaine, acted as the command and support vessel for two strike craft during Operation Interop East. The aim was to strengthen relations with Indian Ocean partners and the flotilla visited Maputo (Mozambique), 
Dar es Salaam (Tanzania), Mombasa (Kenya) and then sailed to the French Island of Reunion. ${ }^{70}$

Quite fittingly, SAS Protea, the oldest ship in the fleet under the command of Captain (SAN) Theo Stokes, was tasked to escort the SA Navy's newest Type 209 submarine, SAS Queen Modjadji, from Kiel to Simon's Town in 2008. This was her first visit to Europe since 1992, and during the voyage she also visited Spain and Germany. ${ }^{71}$ Command of the SAS Queen Modjadji was conferred on Commander A. Souma during a small parade on the helicopter deck of SAS Protea in Emden, Germany, on 31 March. ${ }^{72}$ SAS Protea then sailed through the Kiel Canal to meet up with the submarine in Kiel. On their return voyage, the two vessels sailed around Denmark and made their way home through the English Channel. Due to technical problems, SAS Protea had to put in at Las Palmas on the Canary Islands for a few days to allow the engineers on board to fix the problem. Both ships arrived in South Africa on 22 May 2008. ${ }^{73}$

During both the prestigious Presidential SA Navy Fleet Reviews, in 1997 and 2008, the SAS Protea acted as the Presidential review platform. In 1997, it was President Nelson Mandela who took the salute, while in 2008 it was President Thabo Mbeki. The aim of the Fleet Reviews was to demonstrate the capabilities of the SA Navy to the President (also the Commander in Chief) and the nation. After the arrival of its four new frigates and three new submarines, the 2008 Fleet Review provided the opportunity to showcase and introduce the new SA Navy, and to indicate its readiness to protect and defend the national interest and sovereignty of South Africa. ${ }^{74}$

The SAS Protea has also had a hard-working career as survey ship. During the 1970s and early 1980s she surveyed large portions of the Namibian coastline, including the approaches to Walvis Bay and Lüderitz. ${ }^{75}$ New reefs were discovered and a number of previously uncharted dangers to shipping were charted. At this stage, the "entire South African West Coast, from Palgrave Point to Cape Columbine" was considered a "hydrographic void" as only scattered information existed. ${ }^{76}$ As a result, the approaches to harbours in the region were surveyed and a comprehensive coastal survey followed. The focus then moved to the coast of KwaZulu-Natal, and from the early 1990s onward, an extensive East Coast survey, from the 
Mozambican border southwards, commenced. As the SANHO became the first Hydrographic Office in Africa to publish electronic navigation charts in 2003, South African harbours and their approaches had to be resurveyed in order to provide more detail as required by modern navigation equipment.

The tedious survey work can cause confusion at times, particularly when you are perceived as anything from a ghost ship to a security threat. The inhabitants of Seaview (close to Port Elizabeth) were astonished by the mysterious visits of an unidentified ship, presumably a passenger ship, made to their shores on 22 and 23 May 1974. They reported that a ship of roughly 10000 tons, with three decks and at least 30 portholes for luxury cabins, anchored surprisingly close inshore along a dangerous coast. When the Port Elizabeth port authorities could not shed light on the mysterious ship, those with telescopes and binoculars reported that officers were seen walking around, while passengers enjoyed drinks on the well-lit decks. The theory was that she had developed engine problems, anchored to fix the problem, went on sea trials the next day and returned to continue maintenance the next night. ${ }^{77}$ Even the "security police were worried" about the unidentified visitor and a security policeman spent two nights watching the suspicious vessel. However, the Officer Commanding of SAS Donkin, Naval Base Port Elizabeth, "was subsequently able to reassure" the Police about the ship's identity and as Commodore Kinkhead-Weekes, Director Naval Operations, commented to Captain (SAN) Fawthrop of the SAS Protea, the reported "incidents of Seaview make amusing reading". ${ }^{78}$ When SAS Protea went alongside in Port Elizabeth on 24 May, the harbour master announced that the mysterious ship was indeed the SAS Protea, busy with survey work in the area. ${ }^{79}$

The SAS Protea normally spends about 180 days per year at sea on survey operations and has submitted more than 100 completed surveys of the South African coastline, thus ensuring safe passage to the thousands of vessels traversing South African waters annually. These include surveys of extensive sections of the coast of Namibia, the west, east and south coasts of the Cape, South African harbours and their approaches, as well as the northern coastline of KwaZulu-Natal. If one considers the vastness of these coastal sections, the natural and climatological conditions as well as the harsh sea conditions, this is a demanding and often difficult task, requiring patience, accuracy, time, and much determination. 


\section{The Future of South African Hydrography}

Even though the South Africa coastline has been surveyed, some areas (estimated at roughly forty per cent) require surveying in accordance with modern standards. ${ }^{80}$ This is an ongoing task and the immediate future will see the SAS Protea conducting surveys along the southern coastline of KwaZulu-Natal. Urgent survey work must be conducted along the coast between Durban and East London as the current charts are mostly based on various old British Admiralty charts, which may contain relative inaccuracies because of the outdated methods used, specifically as most surveys were done with hand leadlines in the 1920s or 1930s by the first HMSAS Protea, the Africana, or even earlier. The coastline around Port Shepstone, for example, was last surveyed by the first Protea in 1925, using hand leadlines. The charts of sections of the Cape south coast are also based on old surveys, done by the third SAS Protea and the SAS Natal during the 1950s and 1960s, and should be redone. What is, however, often surprising is that in many cases, the new information does not "significantly differ from the old data which is remarkable if one considers the old navigation equipment in use then, compared to modern equipment and the Differential GPS of today" ${ }^{81}$ the problem is often in the detail and the applicability of the data for modern navigation equipment.

Another important requirement is to complete surveys in order to create up-to-date modern electronic navigation charts. In 2003, SANHO became the first African hydrographic office to produce and publish such charts on the continent. These charts are based on the paper navigational charts and have equal standing according to IMO regulations, but on the 1:50 000 charts, 1 millimetre for example represents 50 meters, which is insufficient resolution for complex new navigation equipment with its great zooming capability. Very high levels of accuracy are therefore required and for this purpose, all the South African harbours and their approaches were surveyed and updated. SANHO has made forty-four electronic navigation charts commercially available and maintains up-to-date Notices to Mariners. ${ }^{82}$ As navigation equipment improves and the requirements of the shipping industry develop at a fast pace, constant surveying and resurveying of the coast will have to be done. 
After four decades, the SAS Protea is reaching the end of her service life, and as the Allouette helicopters have been phased out, her helicopter capability can no longer be maintained. Serious consideration is therefore being given to a replacement, and as part of Project Hotel, the SA Navy is currently investigating various options regarding a future platform for hydrographic survey. ${ }^{83}$

Without adequate funding it is impossible for navies to prepare, train, support, maintain and acquire the men and material necessary to fulfil the expectations of governments. In South Africa, the annual estimates of national expenditure (ENE), supplied by the National Treasury, provide insight into past and present budgets. The 2009 ENE made it clear that the main objective of the SA National Defence Force is to defend and protect South Africa, its territorial integrity and its people and to support UN and AU initiatives aimed at promoting peace, stability and security in Africa. ${ }^{84}$ Regarding the role and function of the SA Navy, the ENE also stated that besides its responsibility to defend and protect South Africa and its maritime zones through its combat capability, it must provide an ongoing hydrographic survey capability to ensure safe navigation and meet international obligations. ${ }^{85}$

Hydrographic knowledge of the coast of Africa, by comparison to other regions in the world, is poor, and large sections of the African coastline could be described as dangerous to navigation due to the lack of sufficient data. Charts are often based on surveys that were done with hand leadlines and old, less accurate, navigation equipment. Amidst socioeconomic and security problems, charting is a low priority, but the IHO and a number of maritime states are engaged in capacity building and hydrographic assistance in various forms in their efforts to rectify the situation. It is important to raise awareness amongst the coastal states of Africa on the vital value hydrography has to their sustainable development and their obligation to international shipping in accordance with the principles entrenched in conventions such as the International Convention on Safety of Life at Sea (SOLAS) and others. ${ }^{86}$

In the Southern Africa region, Mozambique has a limited hydrographic capacity, while the coastline of Namibia was surveyed by South Africa. However, as South Africa is a prominent power in Africa, and 
has a reputable hydrographic capability, it should in future play a leading role in hydrography in the region. Though the regional maritime security literature focuses on operations, other ways in which South Africa can provide maritime assistance are often discussed. During the South African Navy and African Renaissance Conference held in Simon's Town during 1997, Vice-Admiral R.C. Simpson-Anderson (chief of the SA Navy) suggested that South Africa could provide expertise, hydrographic survey services, as well as other types of naval assistance and training. ${ }^{87}$ During the first Sea Power for Africa symposium in 2005, hydrography was again emphasised and cooperation between African hydrographic missions was regarded as crucial for the charting of African harbours and maritime zones. ${ }^{88}$ At the second Sea Power for Africa symposium in Abuja, Nigeria in 2006, the participating countries emphasised maritime and naval cooperation in order to enhance maritime security and safety. At the end of the symposium, a resolution focusing on six points was agreed to. The fourth point specifically emphasises special meetings between maritime specialists, notably hydrographers and cartographers. ${ }^{89}$ These good intentions have not permeated into action, and to make such cooperative hydrographic surveys a reality would require greater cooperation between states, probably bi-lateral agreements, as well as the cash, men and material.

\section{Concluding remarks}

The fact that South Africa has established the SA Navy Hydrographic Office, managed to sustain it through the years and provide a sea-going hydrographic service, demonstrates an innovative planning and maintenance capacity that can be considered as quite an achievement. Furthermore, this office has built up quite a reputation for professionalism, has embraced the newest technological challenges and is producing a quality output which is internationally recognised. The contribution SANHO has made is evident from the international recognition and prestigious awards such as the Alexander Dalrymple Award which the SA Navy hydrographer has received.

Though considerable work has been done there is still much to be done and in the case of South Africa, the hydrographic capacity should ideally remain with the SA Navy, as it is probably the only organisation capable of sustaining a professional hydrographic service. The current 
status of hydrographic services in Africa is concerning and must be improved. This would require much commitment from coastal states in the form of capacity building, adequate resources and international cooperation. The reward, however, would be substantial and enduring.

In addition to making a substantial impact in the sphere of hydrography, the survey ships of the SA Navy have also made an important contribution to South African naval diplomacy. Specifically the current Protea has accomplished much as a South African diplomat. Her involvement varies from international assistance and rescue operations to diplomatic missions and naval cooperation. In this way, she contributed towards normalising international relations and even forging new relations after South Africa emerged from years of apartheid isolation. As a reputable survey vessel with a long and accomplished career, her contribution towards making navigation safe is generally respected wherever she goes.

Since its creation in the 1920s, the SA Navy has illustrated its commitment to hydrography by successfully operating and maintaining a number of survey vessels. The three Proteas and other survey vessels (notably the SAS Natal) have made a major contribution to charting large sections of the South African coast and to hydrography in the region. This is truly a milestone and an achievement South Africa can justly be proud of. Even though it might sound dramatic, the name Protea has become a legend amongst seafaring men.

1 M Siko. South Africa's maritime interests and responsibilities. Simon's Town: South African Navy Publications Unit, N.d., c.1996, 3-6. See also D Burger (ed). South Africa Yearbook 1998. Pretoria: Government Communications, 1998, 475.

2 The Hydrographer SA Navy. Hydrography in the SA Navy [brochure]. Tokai: South African Navy Hydrographic Office, N.d., c.2000, 2.

3 A Kampher. "Hydrography in Africa". Position IT. 9 October 2008. See also A Kampher. "The South African Navy Hydrographic Service”. Article awaiting publication. 1.

4 United Nations. "Oceans and the law of the sea”. UN General Assembly Resolution, $\quad$ A/RES/53/32. $\quad 25 \quad$ November 1998. <http://www.un.org/Depts/dhl/resguide/r53.htm> Accessed on 24 July 2010. The Hydrographer SA Navy op. cit., pp. 2-3.

Kampher, "South African Navy Hydrographic Service” op. cit., pp. 2-3. The Hydrographer SA Navy op. cit., p. 3. 
B Brommer (ed). Grote atlas van die Verenigde Oost-Indische Compagnie, Deel V: Afrika. Voorburg: Asia Maior, 2009, 64-65, 68-69.

9

Brommer op. cit., pp. 202-203, 224.

Ibid., pp. 204-205, 208-209, 223.

Nationaal Archief Nederland, VOC11222, Concept Instructie voor de opperhoofde van de Scheepen der generale Neederlandsche geoctroijeerde Oost Indische Comp zoo van hier na Indien gaande als van daar herwaarts komende en de Tafelbaaij aan Cabo de Goede Hoop willende aandoen, N.d. (probably mid eighteenth century).

JC Goosen. Ons vloot: Die eerste vyftig jaar. Cape Town: WJ Flesch, 1973, 2931.

Goosen op. cit., pp. 32-33.

TD Potgieter. "Die geskiedenis van Projek Taurus en die Missielbootprojekte". MA thesis. Rand Afrikaans University (now University of Johannesburg), 1992, 15.

Cape Times. 13 January 1922.

CH Bennett \& AG Söderlund. South Africa's Navy: A navy of the people and for the people. Simon's Town: SA Navy, 2008, 139.

Goosen op. cit., p. 33.

Ibid., pp. 34-35.

AK du Toit. South Africa's fighting ships: Past and present. Rivonia: Ashanti, 1992, 16.

TD Potgieter. "South African naval vessels in the Mediterranean during the Second World War”. Journal for Contemporary History 23/1. 1998. 52-54.

Kampher, "South African Navy Hydrographic Service” op. cit., p. 1.

SA Navy. Maritime doctrine for the SA Navy - SANGP 100. Simon's Town:

Naval Publications Depot, 2006, 58. Also available at

$<\underline{\text { http://www.navy.mil.za/> }}$

Kampher, "South African Navy Hydrographic Service” op. cit., p. 3.

"Role of the SA Navy". SA Navy. N.d. <http://www.navy.mil.za/aboutus/role/index.htm\#02> Accessed on 7 June 2010.

C Szabo. "South African Navy wins hydrography award: Why it matters". Digital Journal. 6 July 2009. <http://www.digitaljournal.com/article/275442> Accessed on 21 July 2010.

United Kingdom Hydrographic Office. South African hydrographer honoured for his achievements. United Kingdom Hydrographic Office. 18 June 2009. $<$ http://www.ukho.gov.uk/Media/Press\%20Release/WHD09_SA_H_honoured.p df $>$ Accessed on 24 July 2010.

Goosen op. cit., p. 179.

See the Natal Mercury and Sunday Post of 9 March 1950.

Du Toit op. cit., p. 192.

See the HMSAS Protea and SAS Protea logbooks in the South African Department of Defence Archives (hereafter DOD Archives), GP5, Box 96, Ships logs, Logbooks HMSAS Protea, March 1951 - December 1951; GP5 Box 97, Ships logs, Logbooks SAS Protea, January 1952 - December 1952.

Du Toit op. cit., pp. 190-191.

Bennett \& Söderlund op. cit., p. 140. 
33 Armscor Archive (hereafter AA) K15/5/2 Vol. 1, Kontrakte en ooreenkomste, Contract between Yarrow (Shipbuilders) Ltd and the Armaments Board, 7 November 1969.

AA K12/6, Survey Ship, Vol. 2, British Ministry of Defence to Yarrow Ltd, 6 August 1969.

AA K12/6, Survey Ship, Vol. 6, Projekspan aan hoofbestuurder KTR, 3 November 1970; K12/6, Survey Ship, Vol. 10, SAS Protea: Uitstel van aangewese datum, 21 January 1972.

AA K12/6, Survey Ship, Vol. 10, SA Ambassade aan KTR en H Vloot, telex boodskap, 10 January 1972.

AA K12/6, Survey Ship, Vol. 10, SA Ambassade aan KTR en H Vloot, telex boodskap, 6 June 1972.

See the Cape Times and Die Burger. 15 July 1972.

Du Toit op. cit., p. 263; "SAS Protea specifications". SAN Web. $<$ http://www.navy.mil.za/vtour/protea/index.htm> Accessed in July 2010.

SA Navy. SAS Protea [brochure]. Simon's Town: South African Navy Publications Unit, N.d., c. late 1980s and information supplied by Lt. Comm. A Tosh, Engineering Officer, SAS Protea, 1993. See also "SAS Protea Specifications" op. cit.

Du Toit op. cit., p. 263 and information supplied by Lt. Comm. A Tosh, Engineering Officer, SAS Protea, 1993.

Kampher, "South African Navy Hydrographic Service” op. cit., p. 2; interview with Capt. (SAN) A Kampher, SA Navy Hydrographer, 14 July 2010; "SAS Protea Chart Room”. SAN Web. $<$ http://www.navy.mil.za/vtour/protea/chart_room.htm> Accessed on July 2010.

AA, K12/6/6, Survey Ship modifications, Projekbestuurder KTR aan KTR hoofbestuurder, 17 May 1971.

“SAS Protea skeepsverhaal”. Navigasiedataboek, SAS Protea (document kept on board), 50 .

DOD Archives, VSH2/14/1/138, Movements, docking and refits SA ships: SAS

Protea, Vol. 1, Report on voyage to Marion and Prince Edward Islands, 31 March 1977.

DOD Archives, VSH322/1/6, HYD320/15/30021/07, Report of proceedings: Hydrographic Office: 1 January - 31 July 1984, dated 21 August 1984. See also Cape Times. 13 July 1984 and Cape Times. 10 July 1985.

Sunday Times. 22 July 1984.

TD Potgieter. "SAS Protea: Eerste een en twintig jaar”. Navy News, XII. May 1993. 16-17 and information supplied by Lt. Comm. JB de Wet, Executive Officer SAS Protea, 1993.

Cape Argus. 15 March 1975.

DOD Archives, VSH2/14/1/138, Vol. 1, SAS Protea to Chief Navy, Signal, 4 March 1975 and "SAS Protea skeepsverhaal" op. cit. p. 44.

DOD Archives, VSH2/14/6/56 Scientific Cruise Antarctic 1978: SAS Protea, Proposed Hydro-Acoustic Project on Antarctic Krill, January-March 1978, dated 18 December 1976.

DOD Archives, VSH2/14/6/56 Scientific Cruise Antarctic 1978: SAS Protea, handwritten notes by Vice-Admiral Walters, Chief Navy, 20 January 1977. 
53 DOD Archives, GP5 Box 165, SAS PRO skeepsjoernaal, February, March, April 1978; "SAS Protea skeepsverhaal” op. cit., p. 53; Cape Argus. 11 February 1978.

54 DOD Archives, GP1 Box 1, Ships logs, DD708.01 and DD708.05, Logbooks SAS Protea, January 1993 - October 1994; interview with Capt. (SAN) BD Law, former Captain SAS Protea, 14 July 2010.

Ibid. See also JB de Wet. “Operation Breme”. Navy News. XIII. May 1994. 10 11.

56 Interview with Capt. Law, 14 July 2010.

57 DOD Archives, VSH320/15/3138, Verrigtingsverslae SAS PRO, Report of proceedings, 17 May - 13 June 1978.

58 DOD Archives, GP5 Box 165, SAS PRO Skeepsjoernaal, May 1978.

59 DOD Archives, VSH320/15/3138, Verrigtingsverslae SAS PRO, Armstrong to Wagenfeld, 31 May 1978; Die Burger. 25 May 1978.

60 Interview with Kampher, 14 July 2010.

61 "SAS Protea answers mayday call". SA Navy. $<$ http://www.navy.mil.za/archive/0911/091110_Protea_answers_Mayday/article .htm> Accessed in July 2010.

62 DOD Archives, VSH2/14/1/138, Vol. 1, Signals, SAS Protea to Chief Navy, 13 February and 20 February 1976.

63 DOD Archives, VSH320/3/3138, Vol. 1, Operational Order, 19 December 1978; VSH320/15/3138, SAS Protea, not only a guardship, 12 March 1979; Cape Times. 12 January 1979; "SAS Protea skeepsverhaal” op. cit., pp. 47, 52-53, 57.

64 DOD Archives, GP5 Box 165, SAS PRO skeepsjoernaal, January, February, March 1979.

65 Du Toit op. cit., p. 265.

66 BD Law. "The Mediterranean and Black Sea ports visited by SAS Protea". Navy News XI. August 1992. 9-10.

67 DOD Archives, GP1 Box 1, Ships logs, DD708.01 and DD708.05, Logbooks SAS Protea, January 1993 - October 1994; Potgieter, "SAS Protea" op. cit., p. 17.

$68 \quad$ Bennett \& Söderlund op. cit. pp. 61-63.

69 Ibid., pp. 121-123.

70 Interview with Capt. (SAN) MS Blaine, former Captain SAS Protea, 19 July 2010.

71 "Operation Siphelele". SA Navy. <http://www.navy.mil.za/archive/0803/080303_Operation_SIPHELELE/article. htm> Accessed on June 2010.

72 "SAS Queen Modjadji”. SA Navy. <http://www.navy.mil.za/archive/0803/080303_Operation_SIPHELELE/s103_c oc.pdf $>$ Accessed on June 2010.

73 "Heading south". Newsletter 13. 15 May 2008. SA Navy. <http://www.navy.mil.za/archive/0803/080303_Operation_SIPHELELE/news\% 20letter\%2013.pdf> Accessed on July 2010.

74 "Presidential fleet review 2008". SA Navy. <http://www.navy.mil.za/archive/0809/080910_fleet_review/article.htm> Accessed on July 2010. 
75 DOD Archives, VSH322/1/6, Hidrografiese opmeting, HYD521/3/6/2/14, Hydrographic Survey SWA Coast, 16 September 1985.

76 DOD Archives, VSH322/1/6, Hidrografiese opmeting, Requirements for hydrographic and oceanographic information in the short and medium term, 25 April 1980.

77 The Herald. 24 May 1974.

78 DOD Archives, VSH2/14/1/138 Vol. 1, Naval Operations to Officer Commanding SAS Protea, 11 June 1974; Report of proceedings SAS Protea, April - May 1974, 6 June 1974.

79 The Herald. 25 May 1974.

80 Kampher, "South African Navy Hydrographic Service” op. cit., p. 2.

81 Interview with Capt. Blaine, 19 July 2010.

82 Kampher, "South African Navy Hydrographic Service” op. cit., p. 3; interview with Kampher.

83 L Engelbrecht. "SA Navy sketches future design”. defenceWeb. 3 December 2008.

$<$ http://www.defenceweb.co.za/index.php?option=com_content\&task=view\&id $=828$ ?Itemid=419> Accessed on July 2010.

84 Estimates of national expenditure 2009. National Treasury Department. $<$ http://www.treasury.gov.za/documents/national\%20budget/2009/ene/19\%20de fence.pdf $>$ Accessed on August 2009.

85 Ibid.

86 Kampher, "Hydrography in Africa” op. cit., pp. 3-4.

87 RC Simpson-Anderson. "The South African Navy as part of the African Renaissance: Setting the pace for the future". Paper presented at the South African Navy and African Renaissance Conference, Simon's Town, 23 October 1997.

88 I Nhnyete. “The challenges of charting Africa's maritime zones”. Paper presented at the Sea Power for Africa Symposium, Cape Town, 29-31 August 2005.

89 "Resolutions of the Sea Power for Africa Symposium". Sea Power for Africa Symposium. 2006. <http://www.navy.mil.za/Web\%20Seapower_files/Page385.htm> Accessed on August 2009. 